\title{
Record of the occurrence of dinoflagellate Ceratium furcoides in a fish farming lake located in the countryside of São Carlos (SP, Brazil)
}

\author{
L. C. Campanelli ${ }^{*}$, J. G. Tundisi ${ }^{a}$, D. S. Abe ${ }^{a}$, C. Sidagis-Galli ${ }^{a}$, T. Matsumura-Tundisi ${ }^{a}$ \\ anstituto Internacional de Ecologia e Gerenciamento Ambiental - IIEGA, Rua Bento Carlos, 750, Centro, \\ CEP 13560-660, São Carlos, SP, Brazil \\ *e-mail: leandro@iie.com.br
}

Received: May 11, 2016 - Accepted: May 13, 2016 - Distributed: May 31, 2017

(With 2 figures)

Blooms of dinoflagellates, mainly the genus Ceratium sp., have been observed in some freshwater ecosystems, as described in the works of Nakano et al. (1999), Ginkel et al. (2001), Santos-Wisnieswki et al. (2007), Matsumura-Tundisi et al. (2010), Moreira et al. (2015) and Almanza et al. (2016).

It is important to note that, according to Lund (1965), the genus Ceratium sp. can be found in nutrient rich waters, especially phosphate and nitrate, and usually in association with cyanobacteria.

Fieldwork, object of this study, was carried out on March $4^{\text {th }} 2016$, during the morning period, and the climatic conditions were rainy.

The studied area is a lake whose source is associated to the presence of springs and it is located in the countryside of São Carlos (SP), geographic coordinates: $21^{\circ} 54^{\prime} 42.1^{\prime \prime} \mathrm{S} / 47^{\circ} 52^{\prime} 16.1^{\prime}$ 'W. The surroundings are characterized by the absence of riparian vegetation and nearby it is possible to find grazing areas and remaining fragments of native vegetation of the Cerrado. This lake was previously used for fish farming activities (Tilapia farming) for commercial purposes and because of that received food contributions for the maintenance of cultivation.

After an episode of mass mortality of fish, due to sharp decrease in dissolved oxygen levels in the water column, all the dead fish were quickly removed from the system and no fish were introduced again.

On the fieldwork from the referred day, it was executed a vertical profile with the multiparameter probe YSI 6600 - V2 in the center of the lake (depth of 10 meters) as well as the collection of water samples with the support of Van Dorn bottle in the center (including surface and bottom) and at the shore (only surface) of the lake, in order to determine, in the laboratory, nitrate $\left(\mathrm{NO}_{3}^{-}\right)$and ammonium $\left(\mathrm{NH}_{4}^{+}\right)$parameters, according to APHA (1998), and total phosphorus, according to Valderrama (1981).

In the center of the lake it was also performed the collection of a biological sample which was fixed in the field with formaldehyde solution (final concentration of $4 \%$ ), in order to analyze the phytoplankton community.

As a result of the vertical profile performed with the multiparameter probe in the center of the lake, low concentrations of dissolved oxygen were found in the layer below 6 meters deep $(6 \mathrm{~m}=0.41 \mathrm{mg} / \mathrm{L} ; 8 \mathrm{~m}=0.22 \mathrm{mg} / \mathrm{L}$;
$10 \mathrm{~m}=0.29 \mathrm{mg} / \mathrm{L})$. At depths lower than 4 meters, dissolved oxygen concentrations around $5.0 \mathrm{mg} / \mathrm{L}$ were observed.

Still considering the vertical profile, the water temperature observed on the lake surface was $26.37^{\circ} \mathrm{C}$, at a depth of 6 meters it was $25.48^{\circ} \mathrm{C}$ and on the bottom it was $23.23{ }^{\circ} \mathrm{C}$, characterizing the thermal stratification process of this system.

The results obtained for the parameters electric conductivity and total dissolved solids were higher at depths over 6 meters than in relation to the initial portions of the water column. Taking this into account as well as the results of the parameter dissolved oxygen, it was possible to conclude that there are two well characterized compartments in the lake and are metabolically distinct: an upper layer well oxygenated and a lower layer with oxygen low values.

With regard to $\mathrm{NO}_{3}^{-}$, the distribution and concentration of this ion are directly related to the oxygenation of the water column. This explains the higher nitrate results on the surface of the aquatic ecosystem and both in the center $(85.86 \mu \mathrm{g}-\mathrm{N} / \mathrm{L})$ and at the shore $(61.66 \mu \mathrm{g}-\mathrm{N} / \mathrm{L})$. On the bottom of the lake, considering its central region, the concentration was $11.02 \mu \mathrm{g}-\mathrm{N} / \mathrm{L}$.

Regarding the $\mathrm{NH}_{4}^{+}$ion, the very high concentration at the lake bottom $(5035.54 \mu \mathrm{g}-\mathrm{N} / \mathrm{L})$ can be explained by the ammonification process of the nitrate, since conditions of low concentration of dissolved oxygen prevail on the bottom. On the surface of the system, the obtained $\mathrm{NH}_{4}^{+}$concentrations were: $224.97 \mu \mathrm{g}-\mathrm{N} / \mathrm{L}$ (center) and $216.44 \mu \mathrm{g}-\mathrm{N} / \mathrm{L}$ (shore).

For the total phosphorus parameter, high concentrations were identified both on the surface of the lake (center: 64.1 $\mu \mathrm{g}-\mathrm{P} / \mathrm{L}$; shore: $94.31 \mu \mathrm{g}-\mathrm{P} / \mathrm{L}$ ) and on the bottom (center: $1347.69 \mu \mathrm{g}-\mathrm{P} / \mathrm{L}$ ).

Using an inverted microscope Zeiss Axiovert 100 and Utermohl sedimentation chamber $10 \mathrm{~mL}$ for the analyses of the biological sample collected in the center of the lake it was possible to identify high density of the Ceratium furcoides dinoflagellate (978 organisms per ml) (Figures 1 and 2), which corresponds to an invasive species of the lentic freshwater ecosystems. Other phytoplankton genus that also could be observed were: Oscillatoria sp. (Cyanophyceae class), Staurastrum sp. (Zygnematophyceae class) and Gomphonema sp. (Bacillariophyceae class). 


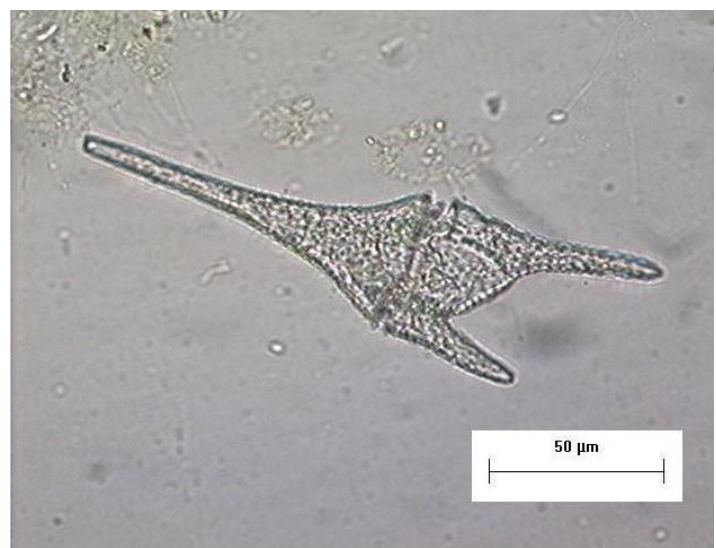

Figure 1. Image of dinoflagellate Ceratium furcoides collected in a fish farming lake located in the countryside of São Carlos (SP, Brazil).

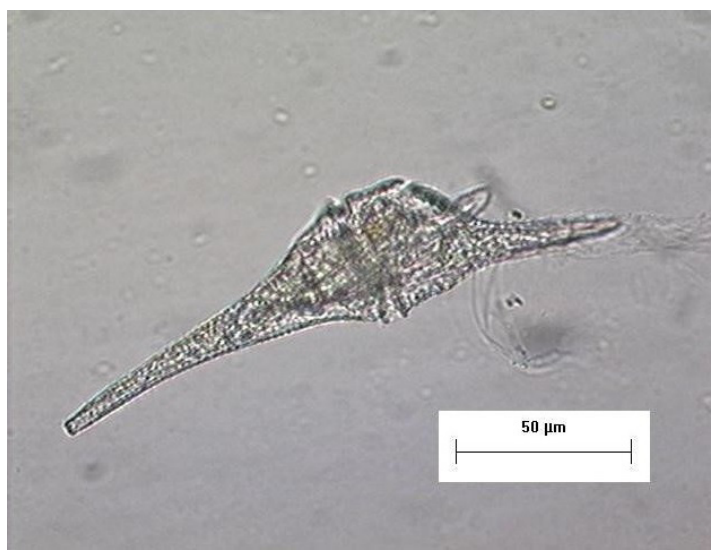

Figure 2. Another image of dinoflagellate Ceratium furcoides collected in a fish farming lake located in the countryside of São Carlos (SP, Brazil).

From the results obtained by this study, some factors that can explain the high density of the Ceratium furcoides dinoflagellate are: high temperatures in the surface layers of the water column; presence of calm waters (low circulation and renewal); high nutrient concentrations in the water column; thermal and chemical stratification.

The occurrence of dinoflagellates, such as Ceratium furcoides, in aquatic ecosystems used for fish farming is problematic because these dinoflagellates can cause episodes of fish mass mortality, mainly due to the clogging of fish gills, hindering gas exchange. It is necessary to evaluate the infestation mechanisms of this dinoflagellate that is developing quickly in freshwater ecosystems in Brazil.

\section{References}

ALMANZA, V., BICUDO, C. E. M., PARRA, O. and URRUTIA, R., 2016. Características morfológicas y limnológicas de las floraciones de Ceratium furcoides (Dinophyta) en un lago somero de Chile Central. Limnetica, vol. 35, no.1, pp. 253-268.

AMERICAN PUBLIC HEALTH ASSOCIATION - APHA, 1998. Standard methods for the examination of water and wastewater. Washington: Byrd Prepress Springfield. 1134 p.

GINKEL, C.E., HOHLS, B.C. and VERMAAK, E., 2001. A Ceratium hirundinella (O.F. Müller) bloom in Hartbeespoort Dam, South Africa. Water S.A., vol. 27, no. 2, pp. 269-276.

LUND, J.W.G., 1965. The ecology of the freshwater phytoplankton. Biological Reviews of the Cambridge Philosophical Society, vol. 40, no. 2, pp. 231-290. http://dx.doi.org/10.1111/j.1469185X.1965.tb00803.x.

MATSUMURA-TUNDISI, T., TUNDISI, J.G., LUZIA, A.P. and DEGANI, R.M., 2010. Occurrence of Ceratium furcoides (Levander) Langhans 1925 bloom at the Billings Reservoir, São Paulo State, Brazil. Brazilian Journal of Biology = Revista Brasileira de Biologia, vol. 70, no. 3, suppl., pp. 825-829. http:// dx.doi.org/10.1590/S1519-69842010000400013. PMid:21085787.

MOREIRA, R.A., ROCHA, O., SANTOS, R.M., LAUDARESSILVA, R., DIAS, E.S. and ESKINAZI-SANT'ANNA, E.M., 2015. First record of Ceratium furcoides (Dinophyta), an invasive species, in a temporary high-altitude lake in the Iron Quadrangle (MG, Southeast Brazil). Brazilian Journal of Biology $=$ Revista Brasileira de Biologia, vol. 75, no. 1, pp. 98-103. PMid:25945626.

NAKANO, S., NAKAJIMA, T., HAYAKAWA, K., KUMAGAI, M. and JIAO, C., 1999. Blooms of the Dinoflagellate Ceratium hirundinella in large enclosures placed in Lake Biwa. Japanese Journal of Limnology, vol. 60, no. 4, pp. 495-505. http://dx.doi. org/10.3739/rikusui.60.495.

SANTOS-WISNIESWKI, M.J., SILVA, L.C., LEONE, I.C., LANDARES-SILVA, R. and ROCHA, O., 2007. First record of the occurrence of Ceratium furcoides (Levander) Langhans 1925, an invasive species in the hydroelectricity power plant Furnas Reservoir, MG, Brazil. Brazilian Journal of Biology $=$ Revista Brasileira de Biologia, vol. 67, no. 4, pp. 791-793. http://dx.doi. org/10.1590/S1519-69842007000400033. PMid:18278340.

VALDERRAMA, J.C., 1981. The simultaneous analysis of total nitrogen and phosphorus in natural waters. Marine Chemistry, vol. 10, no. 2, pp. 109-122. http://dx.doi.org/10.1016/03044203(81)90027-X. 